Abstract 562 Table 1 Kaplan-Meier survival curve for overall survival with groups in total stage

\begin{tabular}{|c|c|c|c|c|c|c|c|}
\hline & \multirow[t]{2}{*}{ Mean } & \multirow[t]{2}{*}{ Median } & \multirow{2}{*}{$\begin{array}{l}\% 1 \\
\text { year }\end{array}$} & \multirow{2}{*}{$\begin{array}{l}\% 3 \\
\text { year }\end{array}$} & \multirow{2}{*}{$\begin{array}{l}\% 5 \\
\text { year }\end{array}$} & \multicolumn{2}{|c|}{ Log rank } \\
\hline & & & & & & $\overline{x^{2}}$ & $p$ \\
\hline \multicolumn{8}{|c|}{ Groups } \\
\hline IDS & 38.50 & 32.0 & 94.7 & 49.2 & 36.9 & 3.046 & 0.081 \\
\hline PDS & 51.80 & - & 84.4 & 68.9 & 61.3 & & \\
\hline
\end{tabular}

Abstract 562 Table 2 Kaplan-Meier survival curve for overall survival with groups in stage 3

\begin{tabular}{|c|c|c|c|c|c|c|c|}
\hline & \multirow[t]{2}{*}{ Mean } & \multirow[t]{2}{*}{ Median } & \multirow{2}{*}{$\begin{array}{l}\% 1 \\
\text { year }\end{array}$} & \multirow{2}{*}{$\begin{array}{l}\% 3 \\
\text { year }\end{array}$} & \multirow{2}{*}{$\begin{array}{l}\% 5 \\
\text { year }\end{array}$} & \multicolumn{2}{|c|}{ Log rank } \\
\hline & & & & & & $\bar{x}^{2}$ & $p$ \\
\hline \multicolumn{8}{|c|}{ Groups } \\
\hline IDS & 37.69 & 32.0 & 92.3 & 48.3 & 38.6 & $5.526^{\star}$ & $0.019^{*}$ \\
\hline PDS & 55.72 & - & 91.2 & 77.1 & 67.5 & & \\
\hline
\end{tabular}

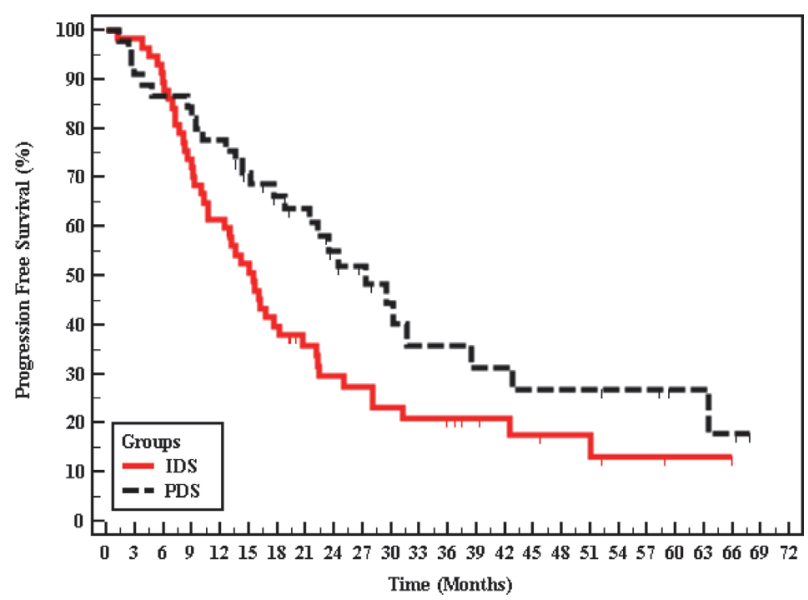

Abstract 562 Figure 3 Kaplan-Meier survival curve for progression free survival with groups

Abstract 562 Table 3 Kaplan-Meier survival curve for progression free survival with groups

\begin{tabular}{|c|c|c|c|c|c|c|c|}
\hline & \multirow[t]{2}{*}{ Mean } & \multirow[t]{2}{*}{ Median } & \multirow{2}{*}{$\begin{array}{l}\% 1 \\
\text { year }\end{array}$} & \multirow{2}{*}{$\begin{array}{l}\% 3 \\
\text { year }\end{array}$} & \multirow{2}{*}{$\begin{array}{l}\% 5 \\
\text { year }\end{array}$} & \multicolumn{2}{|c|}{ Log rank } \\
\hline & & & & & & $\overline{\chi^{2}}$ & $p$ \\
\hline \multicolumn{8}{|c|}{ Groups } \\
\hline IDS & 23.05 & 15.50 & 61.4 & 21.1 & 13.2 & $4.606^{\star}$ & $0.032^{*}$ \\
\hline PDS & 32.36 & 27.37 & 77.8 & 35.8 & 26.9 & & \\
\hline
\end{tabular}

in contrast to comparing overall survival rates in FIGO stage 4 where the two groups showed no statistical difference $(\mathrm{p}=0.726)$.

Furthermore, 1-year, 3-year and 5-year progression free survival was significantly higher $(\mathrm{p}=0.032)$ in patients who underwent PDS $(77.8 \%, 35.8 \%$ and $26.9 \%)$ in comparison to patients who underwent IDS (61.4\%, 21.1\% and 13.2\%).

Conclusion* IDS and PDS effectiveness is stage dependent in advanced ovarian cancer patients.

\section{OVARIAN CARCINOMA PRECURSOR LESIONS IN A WALK-IN SERIES OF OPPORTUNISTIC AND PROPHYLACTIC SALPINGECTOMIES AT THE TUEBINGEN WOMEN'S HOSPITAL}

${ }^{1} \mathrm{~A}$ Rohner ${ }^{*},{ }^{2} \mathrm{~B}$ Ney, ${ }^{1} \mathrm{M}$ Grube, ${ }^{2} \mathrm{~J}$ Keim, ${ }^{2} \mathrm{H}$ Bösmüller, ${ }^{2} \mathrm{~A}$ Fischer, ${ }^{2} \mathrm{~K}$ Greif, ${ }^{1} \mathrm{~B}$ Krämer, ${ }^{1} \mathrm{~S}$ Hoffmann, ${ }^{1} \mathrm{~F}$ Neis, ${ }^{1} \mathrm{~J}$ Andress, ${ }^{2} \mathrm{~F}$ Fend, ${ }^{1} \mathrm{SY}$ Brucker, ${ }^{2} \mathrm{~A}$ Staebler, 'S Kommoss. ${ }^{1}$ Tuebingen University Hospital, Department of Women's Health, Tuebingen, Germany; ${ }^{2}$ Tuebingen University Hospital, Institute of Pathology and Neuropathology, Tuebingen, Germany

\subsection{6/ijgc-2021-ESGO.431}

Introduction/Background* Epithelial ovarian cancer is nowadays recognized to encompass five major disease entities with High Grade Serous Ovarian Carcinoma representing the most common histologic type. The majority of these cancers originate from fallopian tube precursor lesions including serous tubal intraepithelial carcinomas (STIC), serous tubal intraepithelial lesions (STIL), epithelia with a p53 signature and secretory cell outgrowths (SCOUT). Accordingly it has been suggested that removal of the fallopian tubes, even in women at baseline risk for ovarian cancer may reduce the incidence of this deadly disease. On the other hand risk-reducing salpingo-oophorectomy remains the gold standard for primary prevention of ovarian carcinoma in women at increased risk. Here we aim to investigate the frequency of such precursor lesions in a consecutive series of women undergoing surgery for benign pelvic diseases or primary risk-reduction.

Methodology Patients in which uterine adnexa were removed during elective gynecologic procedures (=opportunistic salpingectomy, oSE) and women undergoing risk-reducing surgery (=prophylactic salpingectomy, pSE) were identified. Serially sectioning and extensively sampling of the fimbriated end (SEE-FIM protocol) was applied in all cases, additional routine p53 and Ki-67 immunohistochemistry was performed in pSE specimens. Histopathologic findings and clinical data were collected.

Result(s)* A total of 457 cases treated at the Tuebingen University Women's hospital between 1.3.2019-31.1.2020 was available for further research. 399 patients underwent oSE $(87,31 \%)$ and 58 surgeries $(12,69 \%)$ were performed for primary prevention. Median patient age was 49 years (30-83) in the oSE-group and 46 years (29-63) in the pSE-group. After oSE precursor lesion were identified in 8 patients $(2,01 \%)$ including STIC $(n=1)$, STIL $(n=1)$, SCOUT $(n=4)$ and $p 53$ signature $(n=2)$. In patients with increased risk for ovarian cancer 6 lesions $(10,34 \%)$ were detected (STIC:n=1; p53-signature: $\mathrm{n}=5$ ).

Conclusion* We were able to demonstrate a relevant number of ovarian carcinoma precursor lesions in a walk-in series of opportunistic and prophylactic salpingectomies. In concordance with published data a higher number of precursor lesions was found after pSE. Further studies will now investigate the impact of specialized pathology review and additional immunohistochemistry (p53/Ki-67) in oSE specimens.

\section{IMPACT OF SARS-COV-2 INFECTION ON TREATMENT RESULTS IN PATIENTS WITH EPITHELIAL OVARIAN CANCER}

S Piątek*, M Bidzinski. maria sklodowska curie national research institute of oncology, gynecologic oncology, warsaw, Poland

10.1136/ijgc-2021-ESG0.432 